\title{
Comparison of Free Zinc Levels Determined by Fluorescent Probes in THP1 Cells Using Microplate Reader and Flow Cytometer
}

\author{
Wiebke Alker ${ }^{1,2} \cdot$ Hajo Haase ${ }^{1,2}$ (D) \\ Received: 30 July 2020 / Accepted: 23 August 2020 / Published online: 31 August 2020 \\ (C) The Author(s) 2020
}

\begin{abstract}
Free zinc is involved in signal transduction within mammalian cells, acting as a second messenger. Gold standard for its analysis is currently the use of metal-responsive fluorescent probes. The present study elucidates the impact of instrumentation used for measuring the resulting fluorescence. The free zinc concentration of THP-1 cells loaded with the fluorescent probes Zinpyr-1 (ZP1) or Fluozin-3 AM (FZ3) was determined using a microplate reader (MPR) and a flow cytometer (FC). Depending on the instrumentation, either low nanomolar (MPR) or picomolar (FC) concentrations of free zinc were observed. The concentrations measured from identical samples by MPR were about 40 (ZP1) or 165 (FZ3) times higher compared with FC. These results demonstrate that the choice of instrumentation has a fundamental impact on the determination of intracellular free zinc concentrations by low molecular weight fluorescent probes.
\end{abstract}

Keywords Free zinc $\cdot$ Flow cytometer $\cdot$ Microplate reader $\cdot$ Zinpyr-1 · Fluozin-3 AM $\cdot$ Fluorescent probes

\section{Introduction}

Zinc ions play a crucial role in numerous signaling pathways. Changes in free zinc concentrations are involved in intercellular communication and act as a second messenger for transmitting information within cells $[1,2]$. In this context, the determination of the intracellular free zinc concentration is of great significance.

Fluorescent probes are useful tools for detection and quantification of metal ions. Their functional principle is based on the binding of the analyte to a metal-specific binding site, inducing an alteration of the optical properties of an attached fluorophore. For detailed information on fluorescent metal ion sensors, the reader is referred to review articles on this subject (e.g., $[3,4]$ ). For zinc, the two cell-permeable and zincselective fluorescent probes Zinpyr-1 (ZP1) and Fluozin-3 AM ester (FZ3) are commonly used for determining the free zinc concentration in cells. Here, the term "free zinc"

Hajo Haase

Haase@TU-Berlin.de

1 Food Chemistry and Toxicology, Technische Universität Berlin, Straße des 17. Juni 135, 10623 Berlin, Germany

2 TraceAge - DFG Research Unit on Interactions of essential trace elements in healthy and diseased elderly,

Potsdam-Berlin-Jena, Germany describes the zinc pool that is not tightly bound to proteins, but relatively weakly bound to low molecular weight ligands $[5,6]$. In order to quantify the free zinc concentration, the following equation by Grynkiewicz et al. can be applied for non-ratiometric probes such as FZ3 and ZP1 [7]:

$$
\left[Z n^{2+}\right]=K_{\mathrm{D}} \cdot \frac{F-F_{\text {min }}}{F_{\max }-F}
$$

Herein, $K_{\mathrm{D}}$ indicates the dissociation constant of the zinc:probe complex, $F$ represents the fluorescence of the probe induced by free zinc present in the cell, $F_{\min }$ the autofluorescence of the probe in the absence of zinc, and $F_{\max }$ the maximum fluorescence of the zinc-saturated probe.

The fluorescence intensity is typically measured by either one of two different types of instruments, microplate readers (MPR) or flow cytometers (FC). This study examines whether the resulting free zinc concentrations are comparable when different techniques are used.

\section{Materials and Methods}

\section{Materials}

Bovine serum albumin (BSA) (Sigma-Aldrich, Germany); Dulbecco's Modified Eagles Medium (DMEM) (PAN- 
Biotech, Germany); fetal calf serum (FCS) (CCPro, Germany); Fluozin-3 AM ester (FZ3) (Thermo Fisher Scientific, USA) N,N, $\mathrm{N}^{\prime}, \mathrm{N}^{\prime}$-tetrakis(2-pyridinylmethyl)-1,2ethanediamine (TPEN) (Sigma-Aldrich, Germany); Zinpyr-1 (ZP1) (Santa Cruz Biotechnology, USA); $\mathrm{ZnSO}_{4} \cdot 7 \mathrm{H}_{2} \mathrm{O}$ (Sigma-Aldrich, Germany). All other chemicals were purchased from standard sources.

\section{Cell Culture}

THP-1 cells (obtained from Leibniz Institute DSMZ-German Collection of Microorganisms and Cell Cultures $\mathrm{GmbH}$, Germany) were cultured in DMEM, containing FCS (10\%), penicillin $(100 \mathrm{U} / \mathrm{mL})$, and streptomycin $(100 \mu \mathrm{g} / \mathrm{mL})$ at $37{ }^{\circ} \mathrm{C}, 5 \% \mathrm{CO}_{2}$, and humidified atmosphere. The medium was changed every two to three days.

\section{Fluorescence Staining and Incubation of the Cells}

THP- 1 cells were seeded into 96 -well plates $\left(2 \times 10^{5}\right.$ cells/per well in $200 \mu \mathrm{L}$ assay buffer; $120 \mathrm{mM} \mathrm{NaCl}, 5.4 \mathrm{mM} \mathrm{KCl}$, $5 \mathrm{mM}_{\text {glucose, }} 1 \mathrm{mM} \mathrm{CaCl}_{2}, 1 \mathrm{mM} \mathrm{MgCl} 2,1 \mathrm{mM} \mathrm{NaH}_{2} \mathrm{PO}_{4}$, $10 \mathrm{mM}$ HEPES, $\mathrm{pH} 7.35$ ), centrifuged (5 $\mathrm{min}$ at $166 \mathrm{rcf}$ ) and the supernatant removed. Subsequently, cells were incubated with incubation buffer (assay buffer with $0.3 \%$ BSA), either $200 \mu \mathrm{L}$ containing $0.5 \mu \mathrm{M} Z \mathrm{ZP} 1$ or $50 \mu \mathrm{L}$ containing $1.0 \mu \mathrm{M}$ FZ3, for 30 min at $37{ }^{\circ} \mathrm{C}, 5 \% \mathrm{CO}_{2}$, and humidified atmosphere. Cells were then washed once with assay buffer to remove extracellular probe before addition of $200 \mu \mathrm{L}$ assay buffer alone $(\mathrm{F})$, or supplemented either with the chelator TPEN $(1-100 \mu \mathrm{M})$ or the ionophore sodium pyrithione (NaPyr, $25 \mu \mathrm{M})$ and $\mathrm{ZnSO}_{4}(1-500 \mu \mathrm{M})$ to induce $F_{\min }$ or $F_{\max }$, respectively. Cells were incubated for additional $30 \mathrm{~min}$ at $37^{\circ} \mathrm{C}, 5 \% \mathrm{CO}_{2}$, and humidified atmosphere before measuring fluorescence intensity.

\section{Measurement of Fluorescence Intensity}

Fluorescence intensity was first measured by MPR (ZP1: Infinite M200, Tecan, Switzerland, FZ3: SPARK, Tecan, Switzerland) (ZP1: $\lambda_{\mathrm{ex}} 492 \mathrm{~nm}, \lambda_{\mathrm{em}}=527 \mathrm{~nm}$; FZ3: $\lambda_{\mathrm{ex}}$ $\left.490 \mathrm{~nm}, \lambda_{\mathrm{em}}=515 \mathrm{~nm}\right)$. Subsequently, 96-well plates were directly transferred into the FC (CytoFLEX, Beckman Coulter, Germany) and single-cell fluorescence measured at $\lambda_{\text {ex }} 488 \mathrm{~nm}$ and a band-pass filter at 525/40 nm.

\section{Results and Discussion}

The apparent free zinc concentration of THP-1 cells varies considerably depending on the instrument used for measuring zinc-dependent fluorescence. For ZP1, fluorescence intensity values measured by MPR $(1.05 \pm 0.30 \mathrm{nM})$ yielded about 40 times higher values for free zinc compared with FC $(0.027 \pm$ $0.006 \mathrm{nM}$ ) even though identical samples were investigated. Applying the equation by Grynkiewicz et al., the calculated result is influenced by the relative ratios of $F$ to $F_{\min }$ and $F_{\max }$ to $F$ [7]. To induce $F_{\min }$, the zinc chelator TPEN was used. For both instruments, concentrations from 1 to $100 \mu \mathrm{M}$ resulted in a comparable ratio of $F_{\min }$ to $F$ of about 0.5 (Fig. 1a). In contrast, the ratio of $F_{\max }$ to $F$ differs between MPR and FC (Fig. 1b). A higher ratio, as in the case of the FC, results in lower calculated free zinc concentrations.

Comparable observations were made with another zincselective probe, FZ3. Free zinc determined by MPR (10.38 $\pm 5.37 \mathrm{nM})$ was 165 times higher than by $\mathrm{FC}(0.063 \pm$ $0.012 \mathrm{nM}$ ). As for ZP1, the ratio of $F_{\max }$ to $F$ is substantially higher when measured by FC (Fig. 1d). In addition, the ratio of $F_{\min }$ to $F$ also differs slightly between approximately 0.2 for MPR and 0.5 for FC (Fig. 1c), contributing to the difference of the calculated free zinc concentrations between the two instruments as a lower ratio of $F_{\min }$ to $F$ results in higher calculated values for free zinc.

In addition to the variance between different instruments, the calculated free zinc concentrations also differ between ZP1 and FZ3, when these are measured on the same device. Even though the probes have different affinities for zinc, with FZ3 being the lower affinity probe $\left(\mathrm{K}_{\mathrm{D}} 8.9 \mathrm{nM}\right)$ compared with $\mathrm{ZP1}\left(\mathrm{K}_{\mathrm{D}} 0.7 \mathrm{nM}\right)[8,9]$, comparable values would have to be expected. However, this only applies if both probes localize to the same intracellular compartments. It has repeatedly been shown that this is not the case for ZP1 and FZ3 $[10,11]$, so the present data do not allow an evaluation of the effect that the choice of different fluorescent probes may have on the resulting free zinc concentration. Notably, in human serum, where compartmentalization is not an issue, FZ3 and ZP1 yield comparable free zinc values, indicating that both probes do give according results (data not shown).

The effect has been observed with two different zincselective fluorescent probes, indicating that it is not a particularity of ZP1 and FZ3, but more likely a general observation that is relevant for other probes, as well, not even being limited to zinc-selective probes. Accordingly, different ratios of fluorescence intensity values between MPR and FC for fluorescent probe-loaded cells, after inducing fluorescence intensity by identical treatment, have also been described by Pasquier et al. analyzing human breast cancer cells with the fluorescent probe Calcein acetoxymethyl ester. The ratio relative to untreated control cells is reported to be higher by FC than by MPR, and the difference between the two measurement approaches amplified with increasing fluorescence intensity [12].

To our knowledge, parallel measurements of free zinc by MPR and FC in the same samples have not been previously reported. Still, a higher calculated free zinc concentration resulting from measurements by MPR compared with FC 


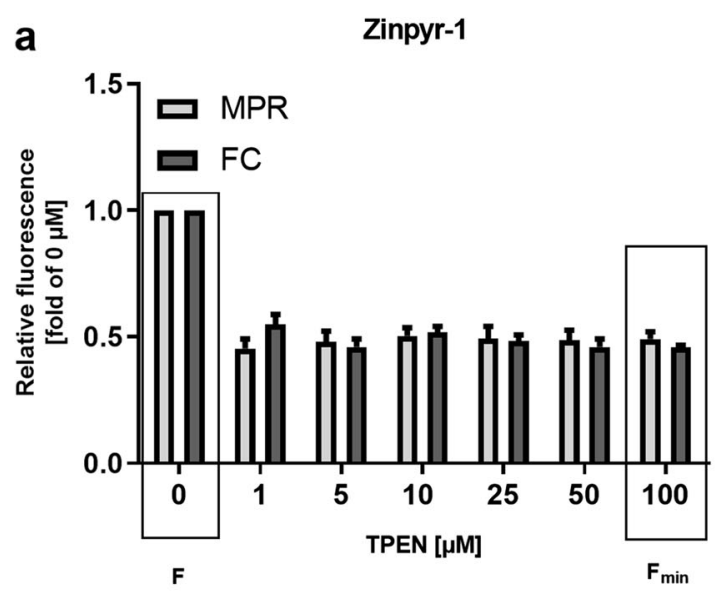

b

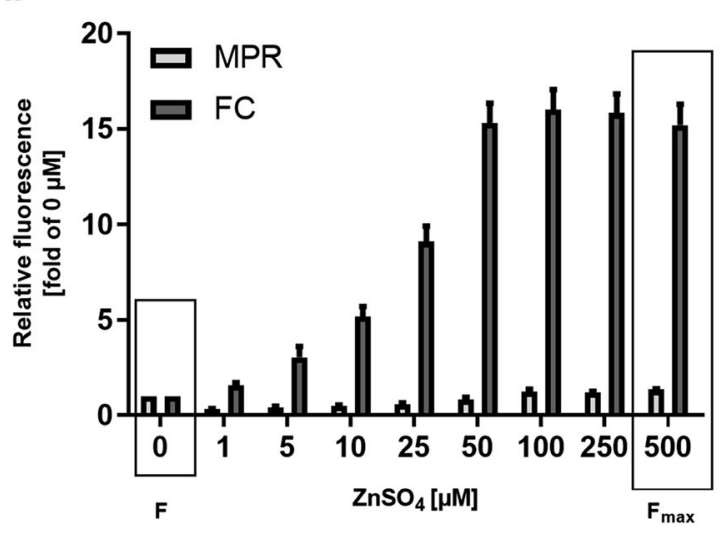

Fig. 1 Relative fluorescence intensity of fluorescent probe-loaded THP1 cells measured by MPR and FC. THP-1 cells were incubated with $\mathbf{a}, \mathbf{b}$ $\mathrm{ZP1}(0.5 \mu \mathrm{M})$ or $\mathbf{c}, \mathbf{d ~ F Z 3}(1.0 \mu \mathrm{M})$ in incubation buffer before addition of either $200 \mu \mathrm{L}$ assay buffer alone $(0 \mu \mathrm{M})$ or containing a, c $1-100 \mu \mathrm{M}$

seems to be a recurring pattern in the literature. The results of different studies that are comparable with regard to their experimental setup typically show nanomolar free zinc concentrations by MPR, while FC yields sub-nanomolar concentrations. In HL-60 cells incubated with FZ3, Dubben et al.

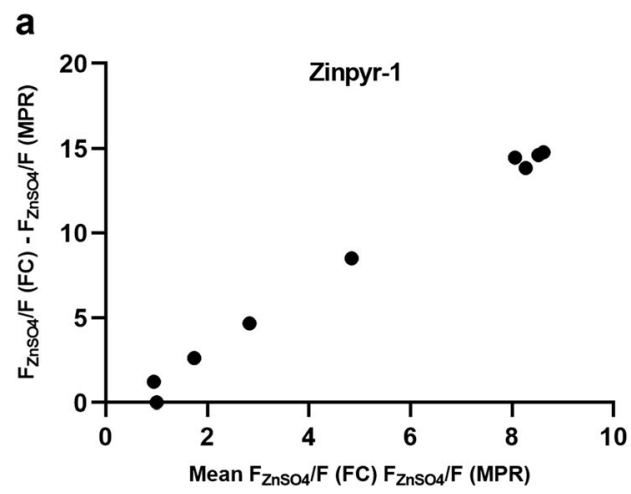

Fig. 2 Difference between zinc-induced increase in fluorescence intensity by FC and MPR plotted against the mean. THP-1 cells were incubated with a ZP1 $(0.5 \mu \mathrm{M})$ or b FZ3 $(1.0 \mu \mathrm{M})$ in incubation buffer before addition of either $200 \mu \mathrm{L}$ assay buffer alone $(F)$ or containing
C

Fluozin-3 AM

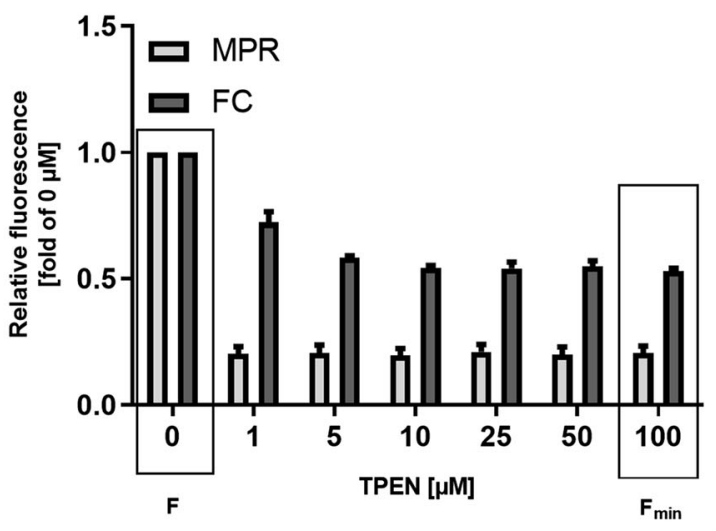

d

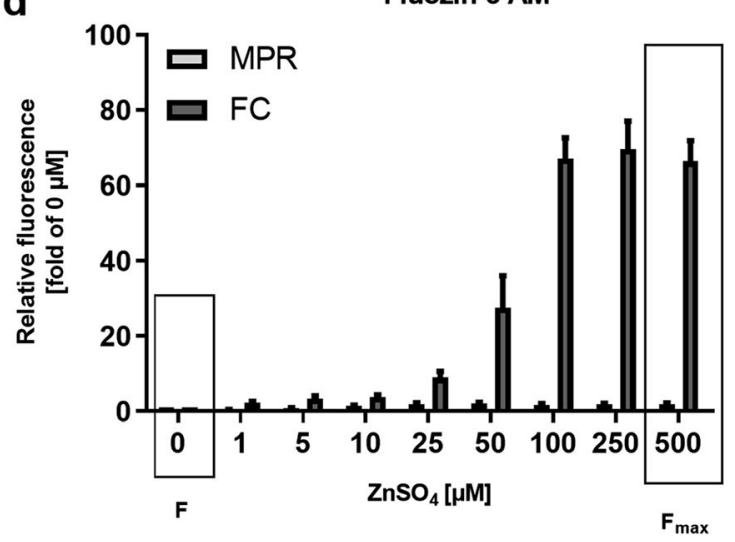

TPEN or b, $\mathbf{d} 25 \mu \mathrm{M}$ NaPyr and $1-500 \mu \mathrm{M} \mathrm{ZnSO}_{4}$. Cells were incubated for $30 \mathrm{~min}$ before read-out of fluorescence intensity by MPR and FC. Data are shown relative to $F$ (fluorescence intensity of $0 \mu \mathrm{M} \mathrm{ZnSO}_{4}$ ) and represent means $+\mathrm{SD}$ of $n=3$ independent experiments

determined a free zinc concentration of $1.75 \pm 0.61 \mathrm{nM}$ using an MPR, whereas Wessels et al. reported approximately $0.04 \mathrm{nM}$ using a FC $[13,14]$. In monocytes and lymphocytes from peripheral venous blood incubated with FZ3, the calculated free zinc concentrations were approximately $2.5 \mathrm{nM}$ and

b

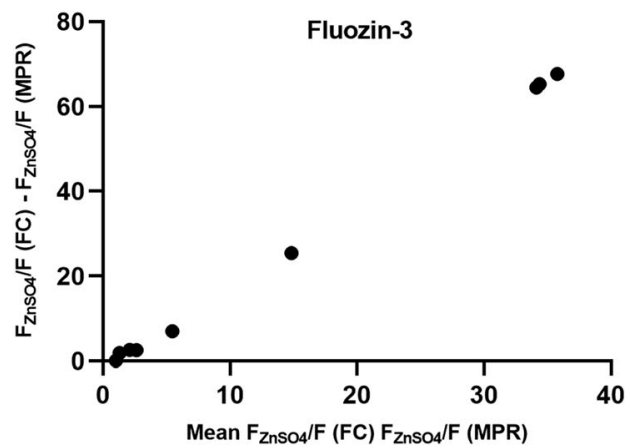

$25 \mu \mathrm{M}$ NaPyr and $1-500 \mu \mathrm{M} \mathrm{ZnSO}_{4}\left(\mathrm{~F}_{\mathrm{ZnSO} 4}\right)$. Cells were incubated for $30 \mathrm{~min}$ before read-out of fluorescence intensity by MPR and FC. Data represent means of $n=3$ independent experiments 

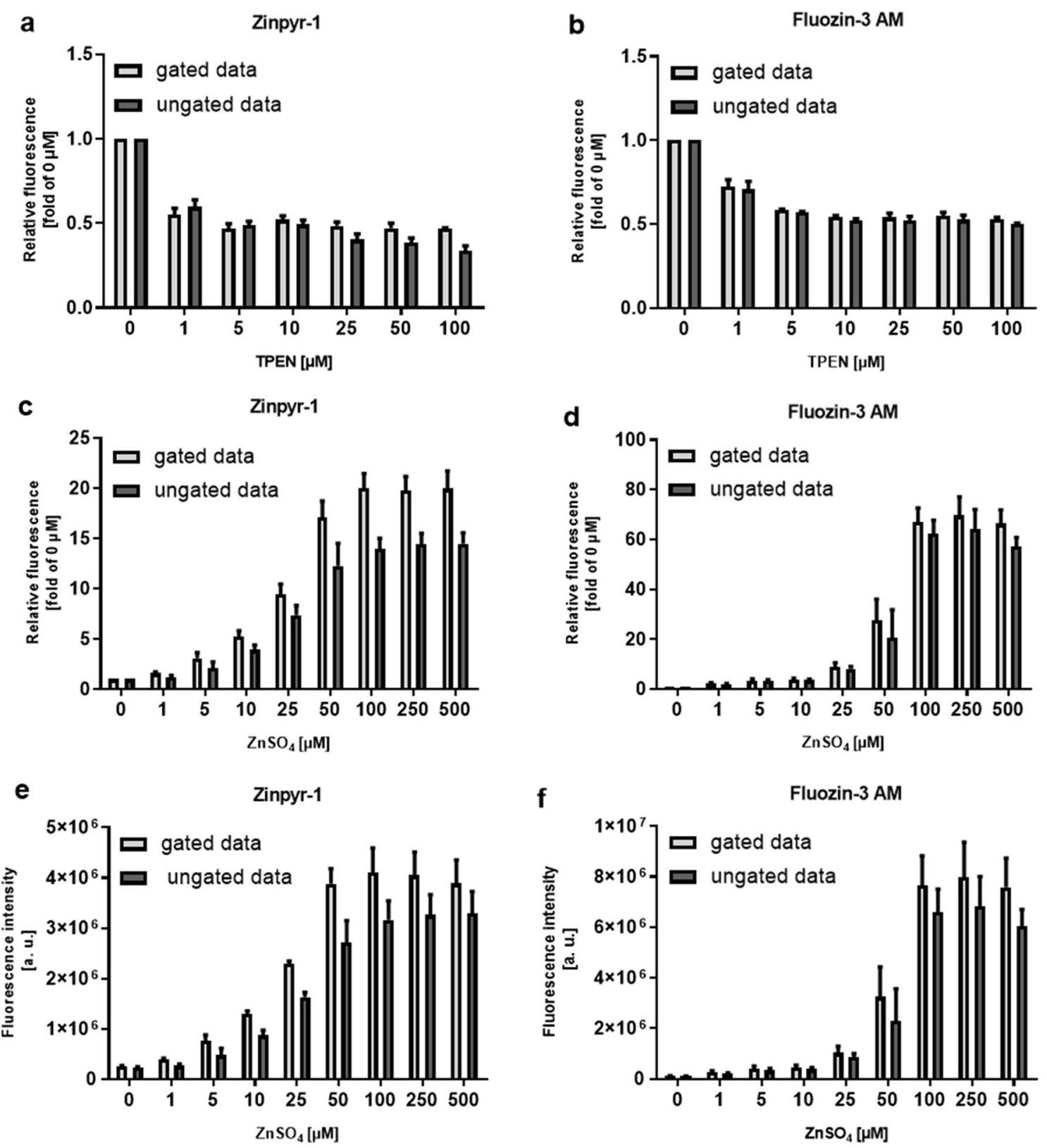

g

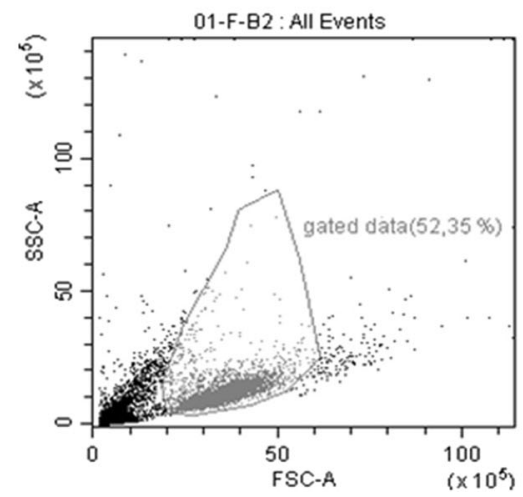


4 Fig. 3 Comparison of different data processing of fluorescence intensity values of fluorescent probe-loaded THP-1 cells measured by FC. THP-1 cells were incubated with ZP1 $(0.5 \mu \mathrm{M})(\mathbf{a}, \mathbf{c}, \mathbf{e}, \mathbf{g})$ or FZ3 $(1.0 \mu \mathrm{M})(\mathbf{b}, \mathbf{d}$, f) in incubation buffer before addition of either $200 \mu \mathrm{L}$ assay buffer alone $(0 \mu \mathrm{M})(\mathbf{g})$ or containing $1-100 \mu \mathrm{M}$ TPEN $(\mathbf{a}, \mathbf{b})$ or $25 \mu \mathrm{M} \mathrm{NaPyr}$ and $1-$ $500 \mu \mathrm{M} \mathrm{ZnSO}_{4}(\mathbf{c}, \mathbf{d}, \mathbf{e}, \mathbf{f})$. Cells were incubated for $30 \mathrm{~min}$ before readout of fluorescence intensity by FC. Data are shown relative to $F$ (fluorescence intensity of $0 \mu \mathrm{M}$ TPEN or $\left.\mathrm{ZnSO}_{4}\right)(\mathbf{a}, \mathbf{b}, \mathbf{c}, \mathbf{d})$ or as fluorescence intensity in arbitrary units $(\mathbf{e}, \mathbf{f})$ and represent means $+\mathrm{SD}$ of $n=3$ independent experiments or as dot plot, showing forward scatter (Fsc) and sideward scatter (Ssc) (g). Ungated data include all measured events (g, black and gray events), and gated data include selected cells only (g, gray events)

$4.4 \mathrm{nM}$ determined by MPR, compared with $0.17 \pm 0.06 \mathrm{nM}$ and $0.35 \pm 0.07 \mathrm{nM}$ by FC, respectively $[15,16]$.

In the present study, identical single-cell suspensions were analyzed by two different instruments; therefore, the cause of the observed differences must lie in the instrumentation. When comparing the results of two methods, Bland and Altman suggest plotting the differences against the mean as this allows conclusions about the comparability of the methods [17]. As $F$ represents the fluorescence intensity induced by free intracellular zinc and $\mathrm{F}_{\mathrm{ZnSO} 4}$ the fluorescence intensity induced by incubation with increasing zinc concentrations, the value for $F$ is constant while $\mathrm{F}_{\mathrm{ZnSO}}$, and thereby the ratio of $\mathrm{F}_{\mathrm{ZnSO} 4}$ to $F$, increases when $\mathrm{ZnSO}_{4}$ is added. In Fig. 2, a proportional increase of the ratios of $\mathrm{F}_{\mathrm{ZnSO} 4}$ to $F$ determined by MPR and FC would lead to a constant relation between the difference of the ratios determined by both methods (depicted on the y-axis) to their means (shown on the $\mathrm{X}$-axis). This is not the case for either fluorescent probe. There is a smaller increase of $\mathrm{F}_{\mathrm{ZnSO} 4}$ by MPR than by $\mathrm{FC}$, indicating a decreasing sensitivity of the MPR for higher fluorescence intensity, compared with FC. Such an observation has also been made by Pasquier et al. in a comparable context [12] and has to be considered when trying to explain the observed discrepancies.

An MPR light passes through the single-cell suspension and fluorescence intensity is recorded as the sum of zincbound ZP1 molecules within a well. Neither during data recording nor data processing it is possible to gain any further information, such as size or intactness of the respective cells that are source of the fluorescence signal. On the other hand, in a FC, the cells pass a laser one by one. In addition to fluorescence intensity, information about size and granularity is measured and can be assigned to each recorded event. As a result, it is possible to select cells of interest for subsequent data processing, which is a common procedure for flow cytometry and often referred to as gating, shown as an example in Fig. 3 g. Subsequent analysis is then based on fluorescence intensity values from these gated cells only, instead of all measured events. This had been performed with the FC data shown in Fig. 1 to exclude cell debris.
Using fluorescence signals from all events measured by the FC instead of gated data results in higher calculated free zinc concentrations for ZP1 $(0.037 \pm 0.006 \mathrm{nM}$ instead of $0.027 \pm$ $0.006 \mathrm{nM})$ and FZ3 $(0.077 \pm 0.012 \mathrm{nM}$ instead of $0.027 \pm$ $0.006 \mathrm{nM})$. For both probes, the ratio of $F_{\min }$ to $F$ is comparable between gated and ungated data (Fig. 3a, d), whereas the ratio of $F_{\max }$ to $F$ is smaller without gating (Fig. 3b, e). This ratio decreases either when the value for $F$ gets bigger or the value for $F_{\text {max }}$ gets smaller. Here, the absolute values for both $F$ and $F_{\max }$ are smaller for ungated datasets (Fig. 3c, f). Inclusion of cell debris, which would otherwise be eliminated by the gating process, results in a lower median of ungated fluorescence intensity values compared with the gated dataset. Proportionally, the decrease of $F_{\max }$ is bigger than the decrease of $F$, so the smaller ratio of $F_{\max }$ to $F$ in ungated data is caused by a smaller $F_{\text {max }}$. Excluding cell debris in FC might therefore contribute to the observed differences between both instruments. However, this effect due to data processing is relatively small compared with the overall differences in calculated free zinc concentrations observed between MPR and FC, and cannot be seen as the sole reason for this discrepancy. As FC measures individual cellular fluorescence, while MPR records bulk fluorescence within a well, the latter would also be prone for measuring cell fragments too small to be recorded by FC, at all, and even extracellular fluorescence. Cells were washed to remove extracellular dye, but still probe could be released through leakage during the experiment, which might be a source of considerable perturbation for MPR measurements. Finally, differences in the excitation and detection of the fluorescence signal, based on the different technological setups, may also contribute to the differences in fluorescence intensity ratios and resulting free zinc concentrations when comparing MPR and FC.

\section{Conclusion}

Both MPR and FC can be used to detect the fluorescence intensity of cells incubated with zinc ion-sensitive fluorescent probes. For some experiments, the choice between MPR and FC is of lesser importance, e.g., when only trends or relative changes are investigated. Here, aspects such as instrument availability, sample throughput, or coefficient of variation can be taken as decisive factors. However, when these values are used for quantification of the intracellular free zinc concentration, the choice of instrumentation critically impacts the obtained values. This factor also needs to be considered when comparing literature results obtained using different measurement approaches.

The most important question, which instrument gives a better representation of the actual free zinc concentration, remains unsolved. The present study cannot provide a definitive answer, as the true intracellular zinc concentrations are not 
known. Because MPR includes data from debris and damaged cells, as well as it might pick up extracellular fluorescence from leakage, it seems that the lower, sub-nanomolar values obtained by FC might be more reliable. These are also a better match for values obtained by other methods not based on fluorescent probes $[18,19]$, as well as the sub-nanomolar affinities of many cellular zinc-binding proteins [20].

Acknowledgements Open Access funding provided by Projekt DEAL.

Authors' Contribution Conceptualization, W.A. and H.H.; methodology, W.A. and H.H.; formal analysis, W.A. and H.H.; investigation, W.A.; resources, H.H.; data curation, W.A.; writing-original draft preparation, W.A.; writing-review and editing, H.H.; funding acquisition, H.H.

Funding This work was funded by a grant from Deutsche Forschungsgemeinschaft (TraceAge - DFG Research Unit on Interactions of essential trace elements in healthy and diseased elderly, Potsdam-Berlin-Jena, FOR 2558/1, HA 4318/4-1)

Data Availability Data will be made available upon request.

\section{Compliance with Ethical Standards}

Conflict of Interest The authors declare that they have no conflict of interest.

Ethical Approval Not applicable

Consent to Participate Not applicable

Consent for Publication Not applicable

Open Access This article is licensed under a Creative Commons Attribution 4.0 International License, which permits use, sharing, adaptation, distribution and reproduction in any medium or format, as long as you give appropriate credit to the original author(s) and the source, provide a link to the Creative Commons licence, and indicate if changes were made. The images or other third party material in this article are included in the article's Creative Commons licence, unless indicated otherwise in a credit line to the material. If material is not included in the article's Creative Commons licence and your intended use is not permitted by statutory regulation or exceeds the permitted use, you will need to obtain permission directly from the copyright holder. To view a copy of this licence, visit http://creativecommons.org/licenses/by/4.0/.

\section{References}

1. Beyersmann D, Haase H (2001) Functions of Zinc in signaling, proliferation and differentiation of mammalian cells. Biometals 14:331-341. https://doi.org/10.1023/A:1012905406548

2. Maret W (2017) Zinc in cellular regulation: the nature and significance of "Zinc Signals". Int J Mol Sci 18(11). https://doi.org/10. 3390/ijms 18112285

3. Carter KP, Young AM, Palmer AE (2014) Fluorescent sensors for measuring metal ions in living systems. Chem Rev 114(8):4564 4601. https://doi.org/10.1021/cr400546e
4. Lim NC, Freake HC, Brückner C (2004) Illuminating zinc in biological systems. Chem Eur J 11(1):38-49. https://doi.org/10.1002/ chem.200400599

5. Maret W (2011) Metals on the move: zinc ions in cellular regulation and in the coordination dynamics of zinc proteins. Biometals 24(3): 411-418. https://doi.org/10.1007/s10534-010-9406-1

6. Bozym RA, Chimienti F, Giblin LJ, Gross GW, Korichneva I, Li Y, Libert S, Maret W, Parviz M, Frederickson CJ, Thompson RB (2010) Free zinc ions outside a narrow concentration range are toxic to a variety of cells in vitro. Exp Biol Med (Maywood) 235(6):741750. https://doi.org/10.1258/ebm.2010.009258

7. Grynkiewicz G, Poenie M, Tsien RY (1985) A new generation of $\mathrm{Ca} 2+$ indicators with greatly improved fluorescence properties. $\mathrm{J}$ Biol Chem 260(6):3440-3450

8. Burdette SC, Walkup GK, Spingler B, Tsien RY, Lippard SJ (2001) Fluorescent sensors for $\mathrm{Zn} 2+$ based on a fluorescein platform: synthesis, properties and intracellular distribution. J Am Chem Soc 123(32):7831-7841. https://doi.org/10.1021/ja0100591

9. Krężel A, Maret W (2006) Zinc-buffering capacity of a eukaryotic cell at physiological pZn. J Biol Inorg Chem 11(8):1049-1062. https://doi.org/10.1007/s00775-006-0150-5

10. Kaltenberg J, Plum LM, Ober-Blöbaum JL, Hönscheid A, Rink L, Haase H (2010) Zinc signals promote IL-2-dependent proliferation of T cells. Eur J Immunol 40(5):1496-1503. https://doi.org/10. 1002/eji.200939574

11. Lu Q, Haragopal H, Slepchenko KG, Stork C, Li YV (2016) Intracellular zinc distribution in mitochondria, ER and the Golgi apparatus. Int J Physiol Pathophysiol Pharmacol 8(1):35-43

12. Pasquier J, Rioult D, Abu-Kaoud N, Marie S, Rafii A, Guerrouahen BS, Le Foll F (2013) P-Glycoprotein-activity measurements in multidrug resistant cell lines: single-cell versus single-well population fluorescence methods. Biomed Res Int 2013:676845. https://doi. org $/ 10.1155 / 2013 / 676845$

13. Dubben S, Hönscheid A, Winkler K, Rink L, Haase H (2010) Cellular zinc homeostasis is a regulator in monocyte differentiation of HL-60 cells by $1 \alpha, 25$-dihydroxyvitamin D3. J Leukoc Biol 87(5):833-844. https://doi.org/10.1189/jlb.0409241

14. Wessels I, Haase H, Engelhardt G, Rink L, Uciechowski P (2013) Zinc deficiency induces production of the proinflammatory cytokines IL- $1 \beta$ and TNF $\alpha$ in promyeloid cells via epigenetic and redox-dependent mechanisms. J Nutr Biochem 24(1):289-297. https://doi.org/10.1016/j.jnutbio.2012.06.007

15. Haase H, Ober-Blöbaum JL, Engelhardt G, Hebel S, Heit A, Heine H, Rink L (2008) Zinc signals are essential for lipopolysaccharideinduced signal transduction in monocytes. J Immunol 181(9):64916502. https://doi.org/10.4049/jimmunol.181.9.6491

16. Haase H, Hebel S, Engelhardt G, Rink L (2006) Flow cytometric measurement of labile zinc in peripheral blood mononuclear cells. Anal Biochem 352(2):222-230. https://doi.org/10.1016/j.ab.2006. 02.009

17. Bland JM, Altman DG (1986) Statistical methods for assessing agreement between two methods of clinical measurement. Lancet 1(8476):307-310

18. Simons TJ (1991) Intracellular free zinc and zinc buffering in human red blood cells. J Membr Biol 123(1):63-71. https://doi.org/ 10.1007/bf01993964

19. Peck EJ Jr, Ray WJ Jr (1971) Metal complexes of phosphoglucomutase in vivo. Alterations induced by insulin. J Biol Chem 246(4): $1160-1167$

20. Maret W (2004) Zinc and sulfur: a critical biological partnership. Biochemistry 43(12):3301-3309. https://doi.org/10.1021/ bi036340p

Publisher's Note Springer Nature remains neutral with regard to jurisdictional claims in published maps and institutional affiliations. 